\title{
Radiotherapy Reduced Salivary Flow Rate and Might Induced C. albicans Infection
}

\author{
Nadia Surjadi ${ }^{1}$, Rahmi Amtha ${ }^{2}$ \\ ${ }^{1}$ Undergraduate Program, Faculty of Dentistry Trisakti University, Jakarta 11440, Indonesia \\ ${ }^{2}$ Department of Oral Medicine, Faculty of Dentistry Trisakti University, Jakarta 11440, Indonesia \\ Correspondence e-mail to:nadia.surjadi@gmail.com
}

\begin{abstract}
Radiotherapy has impact in oral health especially on the secretion capacity of the salivary glands. Another impact is the increase of Candida albicans colony. Objectives: To evaluate salivary flow rate in relation with Candida albicans colony in head and neck cancer patients during and after radiotherapy. Methods: Twenty-four head and neck cancer patients in Dharmais Cancer hospital, Jakarta who were undergoing radiotherapy or had undergone radiotherapy and 24 match healthy volunteers were included in the study. Clinical observation carried out by collecting unstimulated salivary flow rate and followed by culture of Candida in Saboraud agar medium. Data were analyzed statistically by Chi-square. Results: Nasopharynx cancer was the most frequent type of head and neck cancers $(87.5 \%)$ followed by tongue cancer (12.5\%) and found in 41-50 years old patients and 51-60 years old patients, respectively with male predilection compare to female (17:7). Approximately $87.5 \%$ of subjects showed decreased salivary flow rate $(0-1.5 \mathrm{~mL} / 10 \mathrm{~min})$ and $12.5 \%$ showed a normal salivary flow rate $(1.01-1.50 \mathrm{~mL} / 10 \mathrm{~min})$ during and after radiotherapy. However, $91.7 \%$ of cancer patients has increased in C.albicans colony during and after radiotherapy compared to control $(p=0.00)$. Conclusion: This study showed that radiotherapy induced hyposalivation and might increase the C.albicans colony.
\end{abstract}

\begin{abstract}
ABSTRAK
Radioterapi menurunkan laju aliran saliva dan meningkatkan infeksi C albicans. Radioterapi memiliki dampak luar biasa terhadap kesehatan rongga mulut terutama kemampuan kelenjar saliva untuk memproduksi sekretnya. Salah satu dampaknya adalah peningkatan jumlah Candida albicans. Objektif: Untuk mengevaluasi laju aliran saliva dan hubungannya dengan koloni Candida albicans pada pasien kanker kepala leher selama dan pasca radioterapi. Metode: Sebanyak 24 orang penderita kanker kepala leher di RS Kanker Dharmais, Jakarta yang sedang dan pernah menjalani radioterapi maksimal 1 tahun pasca radioterapi serta kontrol 24 orang sehat dimasukkan dalam populasi penelitian. Observasi klinik dilakukan untuk mengevaluasi laju aliran saliva tanpa stimulasi, dilanjutkan dengan observasi laboratorik dengan kultur Candida dari sampel penelitian pada media agar Saboraud. Data dianalisis statistik dengan uji Chi-square. Hasil: Pada penelitian ini didapat dua jenis kanker kepala dan leher, yaitu kanker nasofaring (87,5\%) dan kanker lidah 12,5\%, dalam rentang usia 41-50 tahun $(37,5 \%)$ dan 51-60 tahun (37,5\%) subjek dengan perbandingan pria dan wanita 17:7. Sebanyak 87,5\% subjek menunjukkan penurunan laju aliran saliva $(0-1,50 \mathrm{~mL} / 10$ menit $)$ dan $12,5 \%$ subjek kanker menunjukkan laju aliran saliva yang normal (1,01-1,50mL/10menit) selama dan setelah radioterapi. Berbanding terbalik dengan peningkatan jumlah C. albicans, $91,7 \%$ subjek kanker mengalami peningkatan jumlah C.albicans $(p=0,00)$. Simpulan: Penelitian ini menunjukkan bahwa radioterapi mempengaruhi terjadinya hiposalivasi dan mempengaruhi peningkatan jumlah koloni C. albicans.
\end{abstract}

Key words: Candida albicans, laju aliran saliva, radioterapi 


\section{PENDAHULUAN}

Kanker kepala leher adalah kanker yang ditemukan di regio kepala dan leher. Kanker kepala leher yang meliputi kanker rongga mulut, orofaring, nasofaring, hipofaring, serta laring, tidak termasuk kanker otak, mata, dan tulang belakang. ${ }^{1,2}$ Kasus kanker kepala leher banyak ditemukan pada usia dekade keempat dan kelima, serta lebih sering ditemukan pada pria dibandingkan dengan wanita. Kanker leher kepala erat kaitannya dengan penggunaan tembakau dan alkohol dan secara geografis banyak ditemukan di negaranegara dengan tingkat konsumsi tembakau dan alkohol yang tinggi seperti China, India, Bangladesh, dan Pakistan..$^{3-6}$ Tidak semua kanker kepala leher yang telah dideteksi atau telah ditemukan dapat disembuhkan. Namun, semakin dini kanker kepala leher ditemukan dan diobati, semakin besar kemungkinan untuk sembuh. Secara umum, pengobatan kanker dapat dilakukan dengan beberapa cara, seperti pembedahan, radioterapi dengan atau tanpa kemoterapi. ${ }^{3}$

Salah satu cara pengobatan kanker kepala leher yang hingga sekarang paling utama digunakan adalah dengan radioterapi. Radioterapi menggunakan radiasi ionisasi yang menghasilkan energi untuk menghancurkan sel-sel di daerah target dengan merusak materi genetik sehingga tidak dapat melakukan replikasi sel. ${ }^{3,7}$ Radioterapi juga memiliki dampak negatif yaitu sinar radioaktifnya dapat mempengaruhi sel normal. Efek samping atau komplikasi yang ditimbulkan radioterapi dapat bersifat akut maupun kronis yang menetap setelah perawatan. Komplikasi yang bersifat akut adalah mukositis, disfungsi kelenjar saliva, kandidiasis mulut dan penurunan ketajaman rasa. Sedangkan komplikasi kronis timbul dalam kurun waktu tertentu setelah pasien selesai menjalani perawatan radioterapi adalah hiposalivasi, karies radiasi, dan radio-osteonekrosis. ${ }^{3,8-11}$

Salah satu jaringan tubuh yang terkena efek samping radioterapi adalah kelenjar saliva dan mempengaruhi produksi saliva. Prevalensi terjadinya hiposalivasi pada pasien kanker kepala dan leher akibat radioterapi mencapai hampir $100 \%{ }^{12}$ Penelitian pendahuluan menunjukkan bahwa pada pasien kanker yang menerima pengobatan radioterapi terjadi penuruan laju aliran saliva secara bermakna. ${ }^{12,13}$ Saliva memegang peranan penting dalam rongga mulut manusia. Saliva melindungi jaringan di dalam mulut. Aliran saliva membantu membersihkan mulut dari bakteri dan partikel makanan. Proses buffering, khususnya karena kandungan bikarbonat pada saliva, membantu menetralisir asam sehingga melindungi gigi dari proses demineralisasi. Selain itu, saliva juga membentuk lapisan protein pelumas pada email gigi yang dapat mencegah kontak langsung larutan asam dengan email gigi sehingga melindungi gigi dari erosi. Pada fungsi pencernaan, saliva juga membantu melumatkan makanan dan membentuk bolus-bolus makanan yang memfasilitasi penelanan dan pengecapan. ${ }^{12,13}$ Mengingat akan pentingnya peranan saliva di dalam mulut, terutama dalam menjaga keseimbangan flora mulut, perlu diketahui bagaimana pengaruh dari radioterapi terhadap laju aliran saliva pada pasien pasca kemoradiasi serta hubungannya dengan koloni Candida albicans di dalam saliva. Penelitian ini dilakukan dengan tujuan untuk mengetahui perbedaan laju aliran saliva dan pertumbuhan C. albicans pada pasien kanker kepala leher yang sedang maupun telah mendapatkan perawatan radioterapi dibandingkan dengan populasi normal.

Tabel 1. Sosiodemografik populasi penelitian

\begin{tabular}{cccc}
\hline \multicolumn{2}{c}{ Kategori } & $\begin{array}{c}\text { Kanker } \\
\text { Nasofaring } \\
\text { (n) }\end{array}$ & $\begin{array}{c}\text { Kanker } \\
\text { Lidah } \\
\text { (n) }\end{array}$ \\
\hline $\begin{array}{c}\text { Jenis } \\
\text { kelamin }\end{array}$ & Pria & 16 & 1 \\
& Wanita & 5 & 2 \\
& $21-30$ & 1 & 0 \\
Usia & $31-40$ & 1 & 1 \\
& $41-50$ & 9 & 0 \\
& $51-60$ & 7 & 2 \\
& $61-70$ & 2 & 0 \\
& $71-80$ & 1 & 0 \\
Dosis & 5000 & 8 & 0 \\
Radiasi & 70000 & 5 & 2 \\
& 8000 & 3 & 1 \\
& 9000 & 3 & 0 \\
\hline
\end{tabular}

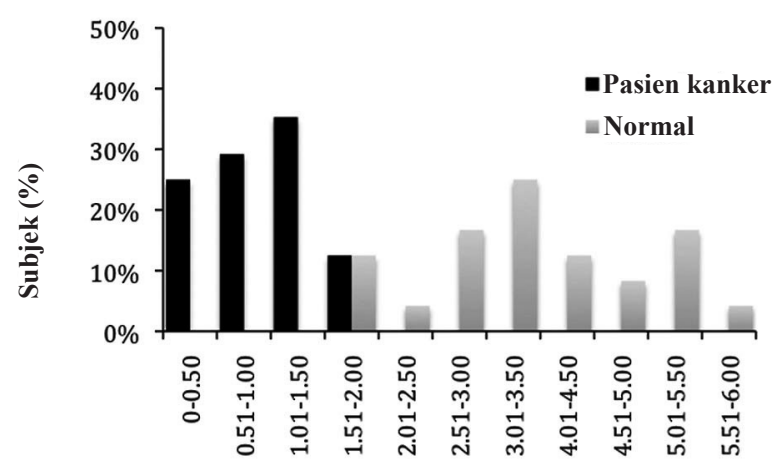

Laju aliran saliva (mL/10menit)

Gambar 1. Distribusi frekuensi laju aliran saliva pada pasien kanker yang menerima radioterapi dan kontrol 


\section{METODE}

Penelitian ini merupakan observasi klinik untuk mengetahui laju aliran saliva pada pasien pasca radioterapi dan laboratorik untuk mengetahui jumlah koloni $C$. albicans yang terdapat pada saliva pasien pasca radioterapi dan kontrol (subjek normal). Jumlah sampel penelitian ditarik dengan menggunakan rumus Lemeshow, dkk. Subjek penelitian adalah pasien yang menderita kanker kepala leher yang sedang menjalani radioterapi (minimal 3 kali radiasi) atau pasien yang telah selesai menjalani radioterapi paling lama 1 tahun. Kriteria inklusi yaitu pasien bersedia mengikuti penelitian dengan menandatangani informed consent. Subjek kontrol adalah orang sehat yang datang ke pusat penelitian dan disesuaikan dengan jenis kelamin dan usia dari kasus yang didapat ( \pm 5 tahun) serta bersedia mengikuti penelitian dengan menandatangani informed consent. Kriteria ekslusi meliputi pasien tidak dapat berkomunikasi dengan baik, tidak kooperatif, memiliki penyakit sistemik atau sedang mengkonsumsi antibiotik. Penelitian dilakukan di Poli Gigi RS Kanker Dharmais pada periode Januari 2011 hingga November 2011 dengan jumlah subjek pada setiap kelompok 24 pasien.

Penentuan laju aliran saliva dilakukan dengan metode spitting tanpa stimulasi, yaitu subjek diminta meludah setiap 1 menit selama 10 menit ke dalam falcon tube. Subjek dikatagorikan mengalami hiposalivasi jika laju aliran saliva di bawah $1,6 \mathrm{~mL} /$ menit (skala nominal). Setelah sampel saliva terkumpul kemudian dibawa ke laboratorium Fakultas Kedokteran Trisakti untuk dibiakkan pada media agar Saboraud dengan pengenceran $10^{-3}$. Koloni $C$. albicans dihitung secara manual dengan membagi 4 area pada cawan petri dan dilakukan penghitungan sebanyak dua kali. Koloni C. albicans pada media agar Saboraud diidentifikasi dengan terlihatnya koloni berwarna putih, halus,

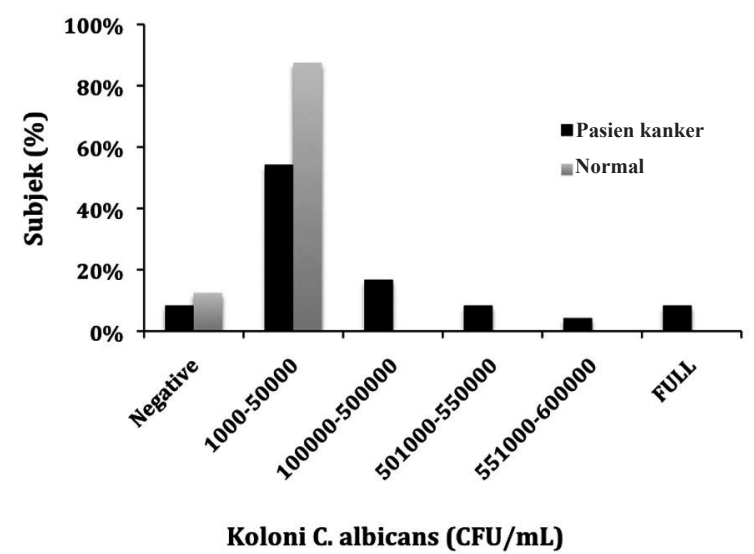

Gambar 2. Distribusi frekuensi jumlah koloni C. albicans pada pasien kanker kepala leher yang menerima radioterapi dan subjek kontrol dan pucat. Kriteria kandidiasis pada penelitian ini adalah apabila terjadi peningkatan koloni $C$. albicans mencapai $>400.000 \mathrm{CFU} / \mathrm{mL}$ (skala nominal). ${ }^{14}$ Data yang diperoleh dianalisis dengan uji beda menggunakan Chi-Square pada SPSS.

Tabel 2. Hubungan antara total dosis radiasi dengan jumlah koloni $C$. albicans

\begin{tabular}{|c|c|c|c|c|c|c|c|}
\hline \multirow{3}{*}{$\begin{array}{l}\text { C. albicans } \\
(\mathrm{CFU} / \mathrm{mL})\end{array}$} & \multicolumn{6}{|c|}{ Dosis radiasi (rad) } & \multirow[t]{3}{*}{$p$} \\
\hline & \multirow{2}{*}{$\begin{array}{l}\mathbf{0} \\
3\end{array}$} & \multicolumn{5}{|c|}{50006000700080009000} & \\
\hline & & 0 & 0 & 1 & 0 & 1 & \\
\hline$>\mathbf{5 0 0 , 0 0 0}$ & 21 & 6 & 5 & 1 & 1 & 0 & \\
\hline $100,000-500,000$ & 0 & 1 & 2 & 0 & 0 & 1 & \\
\hline $500,000-550,000$ & 0 & 0 & 0 & 0 & 1 & 1 & 0,00 \\
\hline $5,50,001-600,000$ & 0 & 1 & 0 & 0 & 0 & 0 & \\
\hline$>620,000$ & 0 & 0 & 0 & 2 & 0 & 0 & \\
\hline
\end{tabular}

Tabel 3. Hubungan antara total dosis radiasi dengan laju aliran saliva

\begin{tabular}{cccccccc}
\hline $\begin{array}{c}\text { Laju aliran } \\
\text { saliva } \\
\text { (mL/10menit) }\end{array}$ & $\mathbf{0}$ & $\mathbf{5 0 0 0}$ & $\mathbf{6 0 0 0}$ & $\mathbf{7 0 0 0}$ & $\mathbf{8 0 0 0}$ & $\mathbf{9 0 0 0}$ & \\
\hline $\mathbf{0 - 0 , 5 0}$ & 0 & 0 & 3 & 1 & 1 & 1 & \\
$\mathbf{0 , 5 1 - 1 , 0 0}$ & 0 & 4 & 1 & 1 & 0 & 1 & \\
$\mathbf{1 , 0 1 - 1 , 5 0}$ & 0 & 4 & 2 & 1 & 1 & 0 & \\
$\mathbf{1 , 5 1 - 2 , 0 0}$ & 3 & 0 & 1 & 1 & 0 & 1 & \\
$\mathbf{2 , 0 1 - 2 , 5 0}$ & 1 & 0 & 0 & 0 & 0 & 0 & \\
$\mathbf{2 , 5 1 - 3 , 0 0}$ & 4 & 0 & 0 & 0 & 0 & 0 & 0,149 \\
$\mathbf{3 , 0 1 - 3 , 5 0}$ & 6 & 0 & 0 & 0 & 0 & 0 & \\
$\mathbf{4 , 0 1 - 4 , 5 0}$ & 3 & 0 & 0 & 0 & 0 & 0 & \\
$\mathbf{4 , 5 1 - 5 , 0 0}$ & 2 & 0 & 0 & 0 & 0 & 0 & \\
$\mathbf{5 , 0 1 - 5 , 5 0}$ & 4 & 0 & 0 & 0 & 0 & 0 & \\
$\mathbf{5 , 5 1 - 6 , 0 0}$ & 1 & 0 & 0 & 0 & 0 & 0 & \\
\hline
\end{tabular}

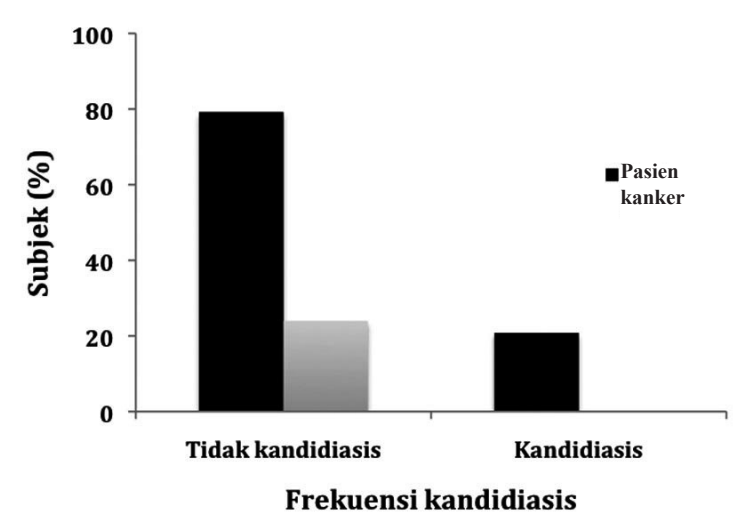

Gambar 3. Distribusi frekuensi (\%) kandidiasis pada pasien kenker kepala leher yang menerima radioterapi * $p=0,018$ 


\section{HASIL}

Seluruh pasien kanker kepala dan leher mendapatkan radiasi dengan pesawat radiasi konvensional. Sebagian besar subjek penelitian mendapat radiasi diatas 5000rad selama kurang lebih 5 minggu dengan dosis perhari antara 100-200rad. Tabel 1 menunjukkan jenis kanker kepala leher yang paling banyak diderita pada penelitian ini adalah kanker nasofaring yaitu 21 subjek (87,5\%) diikuti dengan 3 subjek kanker lidah 12,5\%. Penderita kanker kepala leher paling banyak ditemukan pada kelompok usia 41-50 tahun dan 51-60 tahun, yaitu masing-masing 9 subjek (37,5\%). Jenis kelamin pria lebih banyak terkena kanker kepala dan leher 70,8\% dibandingkan wanita 29,2\%. Total dosis radiasi yang paling sering diberikan kepada pasien kanker kepala dan leher adalah $5000 \mathrm{rad}(33,3 \%)$, diikuti $6000 \mathrm{rad}$ sebanyak $29,2 \%$, dan yang paling jarang diberikan adalah $8000 \mathrm{rad}(8,3 \%)$.

Hiposalivasi $(<1,50 \mathrm{~mL} / 10$ menit) ditemukan pada 21 pasien kanker kepala leher yang menerima radioterapi (87,5\%). Hampir seluruh subjek kontrol memiliki laju aliran saliva normal $(>1,6 \mathrm{ml} / 10$ menit) sebanyak $87,6 \%$ (Gambar 1). Jumlah koloni C. albicans (>400,000CFU/ $\mathrm{mL}$ ) ditemukan pada 5 pasien kanker kepala dan leher yang menerima radioterapi $(20,83 \%)$. Sebaliknya seluruh subjek kontrol memiliki koloni $C$. albicans $<400,000 \mathrm{CFU} / \mathrm{mL}$. Hasil pembiakan koloni C. albicans pada media agar Saboraud ditemukan jumlah koloni C. albicans paling banyak pada pasien kanker kepala leher berkisar antara 1000-50,000CFU/mL (54,2\%) dan jumlah koloni $C$. albicans paling sedikit pada pada pasien kanker antara 550,000-600,000CFU/mL terdapat pada 1 subjek $(4,2 \%)($ Gambar 2$)$.

Hasil uji statistik menunjukkan terdapat hubungan antara dosis radiasi dengan jumlah koloni $C$. albicans $(p=0,00)$ (Tabel 2). Namun tidak hubungan bermakna antara dosis radiasi dengan laju aliran saliva pada penelitian ini $(p=0,149)$ (Tabel 3). Terdapat perbedaan yang bermakna pada jumlah koloni $C$. albicans pada pasien kanker kepala leher yang menerima radioterapi dengan subjek kontrol $(p=0,05)$. Frekuensi kandidiasis pada pasien kanker kepala leher yang menerima radioterapi ditemukan memiliki perbedaan yang bermakna dengan subjek kontrol $(p=0,018)$ (Gambar 3).

\section{DISKUSI}

Penelitian ini dilakukan untuk mengetahui laju aliran saliva dan jumlah koloni $C$. albicans pada pasien yang menerima radioterapi kanker kepala dan leher di Rumah Sakit Kanker Dharmais Jakarta dalam periode Januari 2011 - November 2011.

Penurunan laju aliran saliva yang ditemukan terjadi pada sebagian besar subjek penelitian. Hal ini didukung oleh banyak literatur yang menyatakan bahwa salah satu efek samping dari radioterapi adalah keadaan hiposalivasi. ${ }^{8}$ Selain itu ditemukan juga laju aliran saliva pada pasien kanker kepala dan leher pasca radioterapi yang berkisar antara 1,51-2,00mL/10menit, yaitu 3 subjek $(12,5 \%)$ yang berarti ketiga pasien tersebut belum mengalami penurunan saliva. Hal ini kemungkinan dapat disebabkan karena perbedaan lokasi kanker, jarak pesawat radiasi terhadap kelenjar saliva, total dosis radiasi yang diberikan, serta jumlah kelenjar saliva yang terkena radiasi pada tiap pasien.

Laju aliran saliva pada kelompok kontrol memiliki laju yang normal, yaitu antara 3,01-3,50mL/10 menit. Hal ini mendukung teori yang menyatakan terdapat efek samping pada pasien yang menerima radioterapi daerah kepala leher. Pengambilan sampel saliva pada penelitian ini adalah dengan metode spitting tanpa adanya stimulasi. Data pengambilan sampel ini menunjukkan laju aliran saliva. Pada pasien kanker kepala leher pasca radioterapi berkisar antara $0-0,50 \mathrm{~mL} / 10$ menit $(25 \%) ; 0,51-1,00 \mathrm{~mL} / 10$ menit (29,2\%) dan1,01-1,50mL/10 menit (33,3\%). Hasil ini menunjukkan lebih dari dua pertiga pasien kanker kepala leher pasca radioterapi masuk dalam kategori hiposalivasi adalah $(<0,16 \mathrm{~mL} / \mathrm{menit}) .{ }^{14}$ Hasil laju aliran saliva yang ditemukan pada subjek kontrol pada penelitian ini juga sejalan dengan literatur yang menyatakan bahwa rata-rata laju aliran saliva orang normal berkisar antara $0,25-0,35 \mathrm{~mL} /$ menit. $^{14}$

Hipofungsi kelenjar saliva dan xerostomia merupakan komplikasi yang paling umum diderita oleh pasien kanker kepala dan leher pasca radioterapi. ${ }^{15}$ Penurunan laju aliran saliva yang diakibatkan oleh efek dari radioterapi yang menyebabkan penyempitan pada sel asinar sehingga mempengaruhi jumlah saliva yang disekresi (hiposalivasi). Terapi radiasi pada kanker daerah kepala dan leher, sangat sulit untuk menghindari kelenjar liur mayor (parotis dan kelenjar submandibular) dalam lapangan penyinaran.

Hipofungsi kelenjar saliva ini dapat menimbulkan kondisi seperti kandidiasis karena berkurangnya protein dari saliva seperti Imunoglobulin A, lisosim, laktoferin, dan histatin yang berfungsi untuk menghambat metabolisme mikroorgnanisme di dalam rongga mulut termasuk C.albicans ${ }^{15,18}$ Imunoglobulin A mengikat antigen dan mencegah mikroba dan virus menempel di permukaan mukosa dan gigi. Peningkatan jumlah koloni C. albicans ini juga dapat terjadi karena perubahan kualitas dan kuantitas dari kelenjar saliva. Selain itu pasien yang telah menerima radioterapi kepala leher biasanya sering diikuti dengan mukositis sehingga sulit untuk membersihkan gigi dan mulut yang berakibat meningkatnya jumlah C. albicans.

Jumlah koloni C. albicans pada pasien kanker kepala leher yang menerima radioterapi terlihat meningkat 
pada sebagian besar subjek yang menerima radioterapi dibandingkan kontrol. Data tersebut di atas mendukung hipotesis penelitian bahwa pada pasien dengan radioterapi kepala leher terjadi peningkatan jumlah koloni C. albicans. Pada populasi kontrol, fisiologis kelenjar saliva yang baik dapat menjadi buffer terhadap flora normal pada mulut sehingga jumlah koloni seimbang. ${ }^{16}$

Pada penelitian ini juga ditemukan terdapat hubungan antara total dosis radiasi yang diberikan dengan peningkatan jumlah koloni $C$. albicans. Hal ini memperlihatkan bahwa pasien yang menerima total dosis radiasi kepala dan leher yang lebih tinggi memiliki jumlah koloni $C$. albicans yang lebih banyak. Hal ini dapat terjadi karena semakin tinggi total dosis radiasi yang diberikan, maka penurunan laju aliran saliva semakin hebat sehingga keseimbangan flora mulut di rongga mulut akan terganggu, didukung dengan sifat infeksi oportunistik dari C. albicans dan perlekatan serta pembentukan biofilm dari C. albicans dipengaruhi oleh protein anti mikrobakteri yang dimiliki oleh saliva. ${ }^{17}$

Hasil penelitian berikutnya adalah tidak ditemukan hubungan yang bermakna antara total dosis radiasi dengan laju aliran saliva. Hal ini berbeda dengan literatur. ${ }^{3,8}$ Perbedaan ini kemungkinan disebabkan karena radioterapi yang diberikan pada pasien pasien dalam populasi penelitian letaknya berbeda-beda (ada yang mendekati atau menjauhi kelenjar saliva tergantung dari letak kankernya) sehingga efek yang diterima oleh kelenjar saliva pun menjadi berbeda.

Pada penelitian ini tidak ada hubungan yang bermakna antara laju aliran saliva dengan jumlah koloni $C$. albicans pada pasien. Hal ini berbeda dengan hasil penelitian sebelumnya yang menunjukkan bahwa penurunan laju aliran saliva berbanding terbalik dengan jumlah koloni C. albicans. ${ }^{19}$ Kondisi ini dapat disebabkan karena perbedaan cara, waktu serta alat dan bahan penelitian sehingga mempengaruhi hasil akhir dari penelitian, selain kemungkinan tidak optimumnya pengendalian faktor-faktor luar seperti kebersihan mulut, pemakaian protesa, pemakaian obat kumur, penyakit sistemik yang diderita, serta medikasinya. ${ }^{16}$

Pada penelitian terdapat keterbatasan dalam memasukan faktor-faktor pengganggu seperti kebiasaan merokok, status $\mathrm{OH}$, serta kebiasaan mengkonsumsi air setiap harinya dan ada tidaknya riwayat kemoterapi yang pernah didapat sebelumnya.

\section{SIMPULAN}

Laju aliran saliva pada pasien selama dan pasca radioterapi kepala dan leher terjadi penurunan dan berbanding terbalik dengan jumlah koloni C. albicans jika dibandingkan dengan kelompok yang tidak menerima radioterapi.

\section{DAFTAR PUSTAKA}

1. Scottish Intercollegiate Guidelines Network. Diagnosis and management of head and neck Cancer [Internet]. 2006 [cited 2006 October]. Available from: http://www.sign.ac.uk/pdf/sign90. pdf.

2. Takes RP, Rinaldo A, Silver CE, Piccirillo JF, Haigentz M Jr, Suárez C, et al. Future of the TNM classification and staging system in head and neck cancer. Head Neck. 2010;32:1693-711.

3. Epstein JB. Burket's oral medicine diagnosis \& treatment. Ed. 10th ed. Ontario: BC Decker Inc. 2003.

4. Ragin CCR, Modugno F, Gollin SM. The epidemiology and risk factors of head and neck cancer: a focus on human papillomavirus. J Dent Res. 2007;86:104-14.

5. Cawson RA, Odell EW, editors. Cawson's essential of oral pathology and oral medicine. Ed. 7th Ed. London: Churchill Livingstone; 2003.

6. Trotta BM, Pease CS, Rasamny JJ, Raghavan $\mathrm{P}$, Mukherjee S. Oral cavity and oropharyngeal squamous cell cancer: key imaging findings for staging and treatment planning. Radiographics. 2011;31:339-54.

7. Lodi G, Scully C, Carrozzo M, Griffiths M, Sugerman PB, Thongprasom K. Current controversies in oral lichen planus: report of an international consensus meeting. Part 2. Clinical management and malignant transformation. Oral Surg Oral Med Oral Pathol Oral Radiol Endod. 2005;100:164-78.

8. van der Waal I, de Bree R, Brakenhoff R, Coebergh JW. Early diagnosis in primary oral cancer: is it possible? Med Oral Patol Oral Cir Bucal. 2011;16:e300-5.

9. Villa A, Villa C, Abati S. Oral cancer and oral erythroplakia: an update and implication for clinicians. Aust Dent J. 2011;56:253-6.

10. Visvanathan V, Nix P. Managing the patient presenting with xerostomia: a review. Int J Clin Pract. 2010;64:404-7.

11. Cankaya H, Alpos E, Karabulut G, Guneri P, Boyacioglu H, Kabasakal Y, et al. Effects of hydroxyclhloroquine on salivary flow rates and oral complaints of sjorgen patients: a prospective sample study. Oral Med Oral Pathol Oral Radiol Endod. 2010;110:62-7.

12. Mao L. Oral squamous cell carcinoma - progresses from risk assessment to treatment. Chin J Dent Res. 2012;15:83-8.

13. Spielmann N, Wong DT. Saliva: diagnostics and therapeutic perspectives. Oral Dis. 2011;17:345-54.

14. Torres SR, Peixoto CB, Caldas DM, Silva EB, Akiti $\mathrm{T}$, Nucci $\mathrm{M}$, et al. Relationship between salivary 
flow rates and Candida counts in subjects with xerostomia. Oral Surg Oral Med Oral Pathol Oral Radiol Endod. 2002;93:149-54.

15. Jin Y, Samaranayake LP, Samaranayake Y, Yip HK. Biofilm of candida albicans is variably affected by saliva and dietary sugars. Oral Biol. 2004;49:78998.

16. Parvinen T, Larmas M. Age dependency of stimulated salivary flow rate, $\mathrm{pH}$ and lactobacillus and yeast concentrations" J Dent Res. 1982;61:105255.
17. Navazesh M, Christensen C, Brightman V, Clinical criteria for the diagnosis of salivary gland hypofunction. J Dent Res. 1992;71:1363-9.

18. Robinson PN, Mickelson AR. Early diagnosis of oral cavity cancers. Otolaryngol Clin North Am. 2006;39:295-306.

19. Sevón L, Laine MA, Karjalainen S, Doroguinskaia A, Helenius H, Kiss E, Lehtonen-Veromaa M. Effect of age on flow-rate, protein and electrolyte composition of stimulated whole saliva in healthy, non-smoking women. The Open Dent J. 2008;2:8992. 